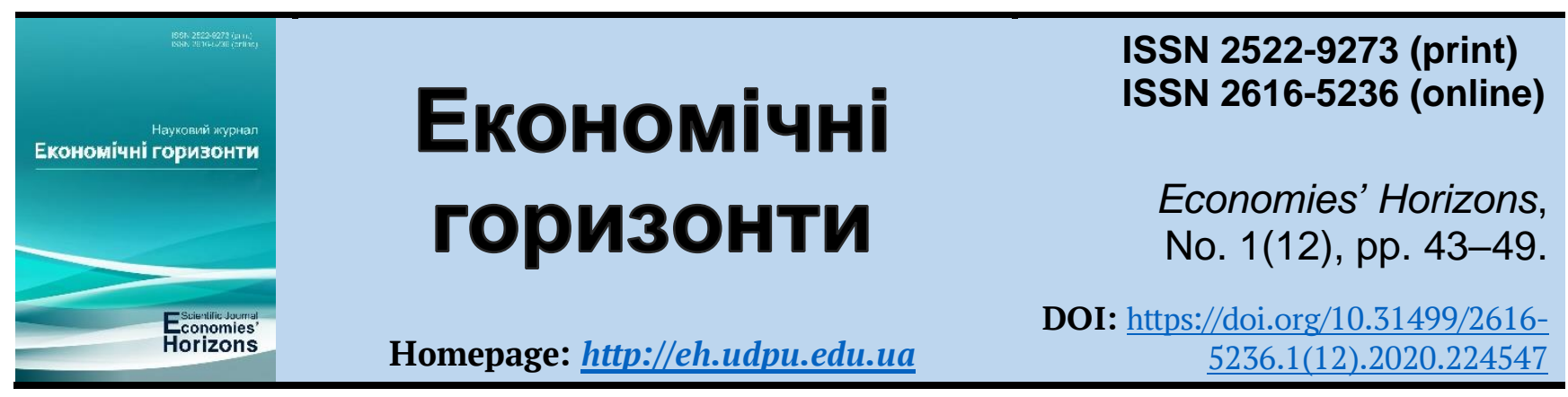

UDC 338.488.2(477)

\title{
Problems of small hotel business development in Ukraine
}

\author{
Inna M. Povorozniuk ${ }^{1}$, Cand. Ec. Sc., Associate Professor \\ Olga G. Chirva ${ }^{2}$, Doctor of Economics, Professor \\ Nataliya M. Maliarchuk ${ }^{3}$, Postgraduate
}

Received: 4 February 2020

Accepted: 6 March 2020

\author{
Povorozniuk, I. M., Chirva, O.G., Maliarchuk, N.M., (2020) "Problems of small hotel \\ business development in Ukraine”, Economies' Horizons, no. 1(12), pp. 43-49. doi: \\ https://doi.org/10.31499/2616- $\underline{5236.1(12) .2020 .224547}$
}

Abstract. Purpose of the research. The research purpose is to analyze the problems of small hotel business development in Ukraine. The reasons of problems in the development of small accommodation establishments and optimal ways of their solution are studied. Methodology. Research methodology is based on the use of laws and regularities of economic science; methodology of system approach implying the complex study of specifics of small hotels activity in conditions of stiff competition. The domestic and foreign theoretical, methodological and practical studies on the hospitality industry are used in the research. Results. The theoretical approach to the development of small hotel business as a structural element of the hospitality industry was substantiated, which allowed to reveal the main problems of its development at all levels. It is proved that the hotel services market in recent years has become the subject of interest of medium and small businesses. In turn, it is becoming increasingly popular among tourists. The main ways to solve the problems of small business in Ukraine should be based on the introduction of new standards for hotel customer service and improving the system of consumer protection, as well as stricter requirements to the safety of guests. It is determined that under conditions of constantly growing competition from international hotel companies it is important to reduce the probability of market development under the influence of chain hotels at the national level and to ensure the national preservation of income. Practical meaning. Practical significance of the obtained results is in their usage in solving urgent problems of small hotel enterprises development in Ukraine. Prospects for further research. The prospects for further research are to justify the directions of imp problems.

Keyword: small business, small hotel business, hospitality industry, mini-hotels, development JEL Classification: O12, M21, Z32.

Number of references: 24; number of tables: 0; number of figures: $\mathbf{0}$; number of formulas: $\mathbf{0 .}$ 


\title{
Проблеми розвитку малого готельного бізнесу в Україні
}

\author{
Інна Миколаївна Поворознюк ${ }^{1}$, к. е. н., доцент
}

Стаття надіŭшла: 04.02.2020 Стаття прийнята: 06.03.2020
Povorozniuk, I. M., Chirva, O.G., Maliarchuk, N.M., (2020) Problems of small hotel business development in Ukraine. Економічні горизонти. 2020. № 1(12). C. 4349. DOI: $\underline{10.31499 / 2616-} \underline{5236.1(12) .2020 .224547}$

Анотація. Мета дослідження. Метою дослідження є аналіз проблем розвитку малого готельного бізнесу в Україні. Досліджуються причини виникнення проблем розвитку малих закладів розміщення та оптимальні шляхи їх вирішення. Методологія. Методологія дослідження базується на використанні законів і закономірностей економічної науки; методології системного підходу, що припускає комплексне вивчення специфіки діяльності малих готелів, в умовах жорсткої конкурентної боротьби. У дослідженні використовувалися вітчизняні та зарубіжні теоретичні, методичні та практичні розробки в індустрії гостинності. Результати. Обгрунтовано теоретичний підхід до розвитку малого готельного бізнесу як структурного елементу індустрії гостинності, що дозволило виявити основні проблеми його розвитку на усіх рівнях. Доведено, що ринок готельних послуг в останні роки стає предметом інтересу середнього і малого бізнесу. У свою чергу все більшою популярністю він користуються у туристів. Основні шляхи вирішення проблем малого бізнесу в Україні повинні базуватися на впровадженні нових стандартів для обслуговування споживачів готельних послуг та вдосконалення системи захисту прав споживачів, а також посилення вимог до забезпечення безпеки постояльців. Визначено, що в умовах постійно зростаючої конкуренції з боку міжнародних готельних підприємств важливо на національному рівні знизити ймовірність розвитку ринку під впливом мережевих готелів, забезпечити збереження доходів на території держави. Практичне значення. Практична значимість отриманих результатів полягає в тому, що вони можуть бути використані для вирішення актуальних проблем розвитку малих готельних підприємств в Україні. Перспективи подальщих досліджень автора полягають в обгрунтовуванні напрямів підвищення якості надання готельних послуг у малих закладах розміщення.

Ключові слова: малий бізнес, малий готельний бізнес, індустрія гостинності, міні-готелі, проблеми розвитку.

Кількість джерел: 24; кількість таблиць: 0; кількість рисунків: 0; кількість формул: 0.

\section{Introduction.}

The small business development is the basis for the social and economic development of the country. It is considered to be the most mobile, reacts to market requirements and introduces innovations faster.

Small business, as one of the important and integral elements of the market economy, provides jobs for a part of the population, including sole proprietors themselves. Additional economic preferences of small and medium enterprises are the growth of gross domestic product, tax payments and economic potential of the country as a whole, improving the quality of life of citizens, as these enterprises are oriented to the most pressing problems and demands of the market in order to meet them.

It is necessary to develop small and medium entrepreneurship in Ukraine, as this will increase the level of economic development in all regions and ensure economic growth of the country as a whole. This is proved by the examples of developed countries, where small business is the leading economic force.

\section{Literature review.}

Numerous works of foreign and domestic scientists are devoted to the study of problems 
of small hotel business development, in particular: M. Porter (1996), R. Braymer (2010), S. Ahmad and A. Arif (2016), A. Barredaa, A. Bilgihanb, N. Khaldoon and F. Okumus (2016), P. Kotler, J. Bowen, S. Baloglu and J. Makens (2016), I. Senenko and V. Shchepak (2016), A. Roper (2017), J. Walker (2017), R. Masa'deh et al. (2017), A. Presbitero (2017), S. Reid, N. Johnston and A. Patiar (2017), E. Nikolskaya (2018), E. Nikolskaya et al. (2018), F. Buffaa, M. Franch, D. Rizio (2018), M. Gürlek and M. Tuna (2019), I. Povorozniuk and I. Kyryliuk (2019), and many others.

Despite the significant achievements of domestic and foreign scientists on the development of small hotel business, the dynamics of changes in the current market situation dictates early intervention, and hotel enterprises desperately need new methods of development and management of their resources for survival and growth.

\section{Methods.}

The following general methods of are used in the research: deduction, induction, analysis and synthesis, as well as special methods: organizational and functional methods and method of comparative analysis.

\section{Research objectives.}

The research objective is to analyze problems of small hotel business development in Ukraine. The reasons of problems and optimal ways to solve them are investigated.

\section{Results and discussions.}

In the EU countries small and medium business accounts for about $90 \%$ of the total number of enterprises. Approximate number of enterprises is about 20 million. The number of employed people is 70\% (Ero, 2019).

According to the Ministry of Economic Development, $99.8 \%$ of all enterprises in Ukraine are small and medium businesses and $79 \%$ of the population work there. According to the UN, small and medium enterprises produce between 30 and $60 \%$ of the national product, depending on the country. Ukrainian small and medium enterprises produce only up to $15 \%$ of GDP (Ministry for Development of
Economy, Trade and Agriculture of Ukraine, 2020).

What hinders the small business development in Ukraine? As the entrepreneurs themselves note, in 2019 it became more difficult to work. Thus, 38.4\% of respondents were dissatisfied with the current state of affairs in business, while $31.6 \%$ of entrepreneurs are quite satisfied with the situation. For comparison, in 2018 positive moods prevailed $-45 \%$ of those satisfied against $26 \%$ of those negatively dissatisfied (Ero, 2019).

Entrepreneurs consider high tax burden, high level of corruption and war in the east of the country to be the main problems. Last year (2019) inflation was in the first place (this year it takes up the 4th place). Among other problems in our country are crediting and state support of business.

Can a small business with an annual turnover of, for instance, 1 million UAH take a loan at $25 \%$ per annum? Obviously, this is almost unreal. There is a vivid example of European neighbours with loans at $2-4 \%$.

We should highlight the problem of lack of awareness of entrepreneurs about tax changes and opportunities for development. For example, there are various credit programs or grants.

For example, the EBRD and the EU are starting a credit line of 3 million euros for small and medium businesses in Ukraine. The programme will help to increase and modernise our export potential.

In addition, there are programs for SMEs as a part of Horizon 2020, Competitiveness of Enterprises and Small and Medium-sized Enterprises (COSME), Erasmus+ (the program budget for 2014-2020 is 14.7 bln EUR). Unfortunately, not all the entrepreneurs are aware of these programs.

As for the development of small hotel business in Ukraine, there has been a significant growth over the past ten years. The hotel industry managers have begun to intensively master the science of hotel business management. As a result, the hospitality industry has become a high-income one. 
So how does the hotel business attract entrepreneurs? Justifying the importance of hotel business in the world, analyzing the global indices of its importance, we came to the conclusion that the reasons for entrepreneurs' interest in conducting small hotel business are as such: relatively small investments; the ability to work effectively in crisis economic conditions; increased demand for tourism and hotel services; high profitability; relatively short payback period; holding various events on different topics.

The standard in the segment of small hotels is considered to be mini-hotels in France, which attract people with their cosiness and uniqueness combined with the reasonable prices. The reform of hotel classification started in 2009 with the entry into force of the French Law "On the development and modernization of tourist services" and led to a redistribution of the hotel market by categories (UNIAN, 2010).

Another example is Switzerland, one of the ancestors of hotel business, where the lion's share falls on small hotels (Baylik, 2006, p. 47).

According to InVenture, the hotel industry development is primarily due to the lowcost airlines, which has led to an increase in the number of foreign tourists. However, according to the forecasts of the World travel and tourism council, the share of tourism in the Ukrainian GDP until 2028 will only grow to $1.7 \%$, and the number of foreigners who will visit Ukraine for the year 2028 will increase to 21 million from the current 15 (the share of tourists among them is less, because statistics take into account transit travellers), which indicates the low attractiveness of Ukraine as a tourist destination. Low rates of the industry development are caused by the lack of favourable legislation and necessary infrastructure for the development of tourism business in Ukraine, the lack of quality hotels (InVenture, 2020).

Development of hotel business in Ukraine has a number of serious problems. One of them is outdated hotels, almost $60 \%$ of which require reconstruction. As practice shows, banks do not want to invest money in restoration and repair, as it is quite expensive. The average payback period is 4-6 years and the owners themselves simply do not have such money, and finding an investor is not easy, especially for small businesses.

High prices for real estate and land hinder the development of the hotel business in many Ukrainian regions. A big obstacle is a great loss of time and material costs for the official registration of hotel business. That is why there are hotels working in formally.

If we take Kyiv as an example, in 2019 about 230 hostels worked illegally (Finance.ua, 2019).

According to the estimates of Kyiv Hostel Association, about $70 \%$ of hostels in Ukraine work in the shadow economy and do not pay taxes (Davydenko, 2019). Not only legalization, but also fair taxation would help improve the situation.

Therefore, in our opinion, it is necessary to introduce strict financial and statistical reporting in order to further plan activities and define development prospects.

Currently small businesses face the problem of a legal framework that does not contribute to their development.

Also, one of the primary problems of small business is the lack of qualified personnel. In Ukraine, there are no reserves of trained workers, and a large amount of time and financial resources is needed for quality training of employees. The work of unqualified hotel staff leads to losses in this area.

The main problems of hoteliers are recruitment, service quality and advertising (Ivanov and Shulepova, 2018).

The next problem is the increasing competition in the sphere of hospitality. The domestic market of hotel services is being penetrated by international chain companies. This is due to the lack of experience of domestic companies in this field. International companies buy out already built hotels, absorb competitors, and build new objects on their own funds and by their own technologies.

We should not forget about seasonality in the work of small means of accommodation. It 
is most often faced with hotels in resort cities, where there is an active demand in the summer months, but almost no other time in other seasons. Solving this problem is also a lot of difficulties, as most cities have nothing to attract tourists in the "off-season" months. Therefore, hotels are idle without visitors for most of the year, and the business owner, again, loses its money.

One of the immediate problems of small hotel business development is booking of rooms. It is not infrequent that the number of sold rooms exceeds the number of available ones. Because of this there is an overlay booking, which leads to unpleasant incidents, after which visitors have a negative impression of the hotel itself. This is due to the uncoordinated work of automatic computer booking systems or due to poor quality work of the hotel employees themselves (also, if the hotel does not have an automatic update of the room availability on its website, the same problem is possible).

At the current stage of management there are a number of other problems that are typical for all small hotel businesses, namely, the use of advanced management and marketing methods, solving automation issues, etc.

The main modern trend for the domestic hotel business is the active introduction of innovations. In the conditions of the modern market for the organization of service sphere business the approach focused on satisfaction of needs of the concrete consumer is necessary.

Many entrepreneurs want to accelerate the payback of their hotel by increasing the price of the offered services, which repels customers and leads to bankruptcy. And most entrepreneurs have no interest in innovative technologies and most of them are aimed at making a profit "here and now".

To ensure the necessary level of competitiveness, it is obvious that the newest information technologies should be used through the introduction of new types of basic and additional services, as well as expanding the use of new Internet communication channels to promote small hotel businesses.
The main factor of success of mini-hotels is a well-developed infrastructure, including transport accessibility, availability of socially important objects (places of rest, attractions, shops etc.). This is because in small hotels the main consumers are middle class businessmen, youth and tourists. They are quite satisfied with moderate comfort, cleanliness and home comfort, delicious cuisine.

The importance of mini-hotels both for tourism development and for the development of the region as a whole is an obvious factor. To overcome these problems, it is necessary to: improve the legislative base, tax legislation, ensure modern standards and quality of service in small hotels.

Also, effective development of small businesses is impossible without taking into account the needs of guests, which are constantly changing. Meeting their wishes is possible only through the introduction of modern automated internet systems that will promote effective and competitive business in the hospitality industry.

It should be noted that in addition to the described problems of small hotel business development, there are problems that should be attributed to the general state of the country. The popularity of the country, the possibility of free movement and establishment of business relations at the international and inter-regional level, all this affects the demand, which in turn forms the prerequisites for the industry development. Therefore, critical factors that hinder the development of hotels in Ukraine are: unstable economic situation in the country. One of the most important factors is periodic financial difficulties among the population, which significantly reduce the need for hotel services for domestic citizens. At the same time, economy class hotels experience the greatest difficulties, as most potential customers completely refuse to provide services. Thus, tourists, having no money, prefer to stay at home, and problems in the sphere of small and medium business reduce the number of business trips. This leads to active demand fluctuations, which are difficult to predict but create serious obstacles for entrepreneurs; 
low popularity of domestic tourism. Even despite the economic downturn, the home country remains not too interesting for Ukrainian citizens, and the most attractive type of tourism for most Ukrainians is the outbound tourism.

low investment attractiveness. Due to the unstable political and economic situation in Ukraine, the prospect of investing in the hotel business is characterized by high risks, both in the domestic and foreign markets. This makes it very difficult to raise funds for the development and expansion of the industry as a whole.

\section{Conclusions.}

Thus, we can see that all these problems are global enough, as they occur everywhere in Ukraine. Because of this, the hospitality sphere itself suffers, as most of our hotels cannot provide the level necessary for productive promotion of this sphere in the future. Accordingly, it is necessary to invest a lot of effort and labour to establish quality service and eliminate all problems.

Hotel business is not an easy business, but with proper management and marketing a good hotel can quickly pay off and start making a profit.

The main ways to solve the problems of small business in Ukraine should be based on the introduction of new standards, as in Western countries emphasize the need for their implementation. The world community itself is changing and as a result new non-traditional forms of hotels appear. Thus, a more concise format is increasingly being applied, which excludes unnecessary luxury attributes and unnecessary services (for example, daily clean- ing). This makes it possible to orient hotels towards middle and business class.

Similar transformations should affect the Ukrainian market as well, which will free up finances for more important problems (e.g. retraining and paying more skilled personnel).

An important point for Ukraine is also the development of domestic tourism, which can be focused on recreational complexes. This will demonstrate to domestic citizens that mini-hotels can act not only as a means for temporary accommodation on business trips or vacations, but also as an option for a long stay, forcing the illegal rent of private apartments out of the market.

At the legislative level, the new point for the Ukrainian hotel business should be based on improving the consumer protection system, as well as stricter requirements to ensure the safety of guests. A very important problem for the domestic market of accommodation services is also the lack of compliance with international standards, and therefore the introduction of a system of qualitative assessment of "star" categories is also important to pay special attention to.

Of course, it is unlikely that we will be able to solve the pressing issues at once, even if we have large capital. However, understanding the main problems of small hotel business development in Ukraine, we will be able to analyse the prospects and potential profitability of such enterprise.

Further research requires substantiation of the direction of improving the quality of hotel services in small accommodation establishments.

\section{References}

Ahmad, S. Z. and Arif, A. (2016), "Entrepreneurial characteristics, motives, and business challenges: exploratory study of small- and medium-sized hotel businesses", International Journal of Hospitality \& Tourism Administration, vol. 17, no. 3, pp. 286-315, doi: https://doi.org/10.1080/15256480.2016.1183550

Barredaa, A., Bilgihanb, A., Khaldoon, N. and Okumus, F. (2016), "Online branding: Development of hotel branding through interactivity theory", Tourism Management, vol. 57, pp. 180-192, doi: https://doi.org/10.1016/j.tourman.2016.06.007

Baylik, S. I. (2006), Gostinichnoe hozyaystvo. Organizatsiya, upravlenie, obslujivanie [Hotel management. Organization, management, service], Kyiv, Ukraine, 288 p.

Braymer, R. A. (2010), Osnovyi upravleniya v industrii gostepriimstva [Management basics in the hospitality industry], Moscow, Russia, 254 p. 
Buffaa, F., Franch, M. and Rizio, D. (2018), "Environmental management practices for sustainable business models in small and medium sized hotel enterprises", Journal of Cleaner Production. no. 194, pp. 656-664, doi: https://doi.org/10.1016/i.jclepro.2018.05.143

Davydenko, Ye. (2019), "Legalization difficulties: why white hostels suffer in Ukraine", available at: https://www.segodnya.ua/ua/economics/business/trudnosti-legalizacii-pochemu-stradayut-belye-hostely1277930.html (Accessed 21 January 2020).

Ero, O. (2019), "How to support small business in Ukraine”, available at: https://eba.com.ua/yak-pidtrymatymalyj-biznes-v-ukrayini/ (Accessed 15 January 2020).

Finance.ua (2019), “About 230 Kyiv hostels operate illegally”, available at: https://news.finance.ua/ua/news/456268/blyzko-230-kyyivskyh-hosteliv-pratsyuyut-nelegalno (Accessed 21 January 2020).

Gürlek, M. and Tuna, M. (2019), “Corporate social responsibility and work engagement: Evidence from the hotel industry", Tourism Management Perspectives, vol. 31, pp. 195-208, doi: https://doi.org/10.1016/j.tmp.2019.05.004

InVenture (2020), “Investment analytics - Ukraine”, available at: https:/inventure.com.ua/en/analytics (Accessed 20 January 2020).

Ivanov, A. and Shulepova, E. (2018), "Hostels and mini-hotels are gaining popularity", available at: https://rg.ru/2018/12/18/reg-cfo/pochemu-hostely-i-mini-oteli-nabiraiut-populiarnost.html (Accessed 20 January 2020).

Kotler, P., Bowen, J., Baloglu S., and Makens, J. (2016), Marketing for Hospitality and Tourism, Pearson, Boston, MA, USA, $688 \mathrm{p}$.

Masa'deh, R., Nasseef, M., Sunna, C., Suliman, M. and Albawab, M. (2017), “The effect of hotel development on sustainable tourism development”, International Journal of Business Administration, vol. 8, no. 4, pp. 16-33, doi: https://doi.org/10.5430/ijba.v8n4p16

Ministry for Development of Economy, Trade and Agriculture of Ukraine (2020), "Activity", available at: https://www.me.gov.ua/Documents/MoreDetails?lang=en-GB\&id=6a9170af-8e4d-4e4c-bb95fa1ae7f43647\&title=activity (Accessed 15 January 2020).

Nikolskaya, E. (2018), “Innovation, technology in the hotel activity”, Bulletin of Science and Practice, no. 4(10), pp. 351-359.

Nikolskaya, E., Lepeshkin, V., Kulgachev, I., Popov, L., Romanova, M. and Lebedev, K. (2018), “Methodological approaches to assessing the innovative potential of enterprises in the hotel business", Revista Espacios, vol. 39, no. ${ }^{0} 27$, available at: https://www.revistaespacios.com/a18v39n27/a18v39n27p30.pdf (Accessed 15 January 2020).

Porter, M. E. (1996), “Competitive advantage, agglomeration economies, and regional policy”, International Regional Science Review, vol. 19, issue 1-2, pp. 85-90, doi: https://doi.org/10.1177\%2F016001769601900208

Povorozniuk, I. and Kyryliuk, I. (2019), “The prospect of development of the hostel market in Ukraine”, Naukovyi visnyk Poltavskoho universytetu ekonomiky $i$ torhivli, no. 4(95), p.113-119, doi: http://doi.org/10.37734/2409-6873-2019-4-14

Presbitero, A. (2017), "How do changes in human resource management practices influence employee engagement? A longitudinal study in a hotel chain in the Philippines", Journal of Human Resources in Hospitality \& Tourism, no. 16, pp. 56-70, doi: https://doi.org/10.1080/15332845.2016.1202061

Reid, S., Johnston, N. and Patiar, A. (2017), "Coastal resorts setting the pace: An evaluation of sustainable hotel practices”, Journal of Hospitality and Tourism Management, vol.33, pp.11-22, doi: https://doi.org/10.1016/J.JHTM.2017.07.001

Roper, A. (2017), "Vertical disintegration in the corporate hotel industry", Journal Current Issues in Tourism, vol. 20, pp. 1-6, doi: https://doi.org/10.1080/13683500.2015.1068282

Senenko, I. and Schepak, V. (2016), "Organization of a small hotel business based on the development of recreational areas”, Economic space, no. 108, pp. 81-89.

UNIAN (2010), "France introduces a new category to the classification of hotels", available at: https://www.unian.ua/common/409392-frantsiya-vvodit-novu-kategoriyu-do-klasifikatsiji-goteliv.html (Accessed 30 January 2020).

Walker, J. R. (2017), Introduction to Hospitality, Pearson, Boston, MA, USA, 621 p.

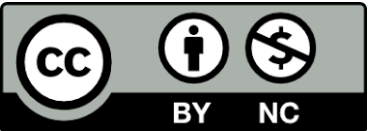

Цей твір ліцензовано на умовах Ліцензії Creative Commons «/з Зазначенням Авторства - Некомерційна 4.0 Міжнародна» (CC BY-NC 4.0). This is an open access journal and all published articles are licensed under a Creative Commons "Attribution-NonCommercial 4.0 International" (CC BY-NC 4.0). 